\title{
Building of Family-based Islamic Character for Children in Tablighi Jamaat Community
}

Received: 11-11-2021; Revised: 24-12-2021; Accepted: 24-12-2021

\section{Engkizar *)}

Universitas Negeri Padang, Sumatera Barat, Indonesia

E-mail: engkizar@ fis.unp.ac.id

\section{Munawir K}

Universitas Islam Negeri Alauddin Makassar

E-mail: munawirkamaluddin@gmail.com

\section{Soni Kaputra}

Universitas Negeri Padang, Sumatera barat, Indonesia

E-mail: soniekaputra15@gmail.com

\section{Zainul Arifin}

Universitas Islam Negeri Imam Bonjol, Sumatera Barat, Indonesia

E-mail: zainularifin@uinib.ac.id

\section{Syafrimen Syafril}

Universitas Islam Negeri Raden Intan lampung, Lampung, Indonesia E-mail: syafrimen@radenintan.ac.id

\section{Fuady Anwar}

Universitas Negeri Padang, Sumatera Barat, Indonesia

E-mail: fuadyanwar@fis.unp.ac.id

\section{Mutathahirin}

Universitas Negeri Padang, Sumatera Barat, Indonesia

E-mail: mutathahirin09@gmail.com

\section{*) Corresponding Author}

\begin{abstract}
This study is aimed at exploring how to build familybased Islamic character in the Tablighi Jamaat community. As a qualitative study, the research was conducted by using an ethnographic approach. The data were collected through direct interviews with ten informants which are the heads of the family that belong to the Tablighi Jamaat community. Moreover, the researcher was also involved in some religious activities of the community for two years that the observation during the activities can be used to reinforce the result of the interviews. Those activities are Ijtima' (annual gathering), Bayan Markas (sermon), Ta'lim Halaqah, Khuruj (proselytizing tour), Jaulah, and some informal visits to interviewees' families. All data, both interviews and direct observation, were thematically analyzed by using specific software, namely NVivo 12 . Based on the data it is found that there are five major Islamic characters could be developed through the family-based character building in the Jama'ah Tablghi community, namely: (1) good moral conduct to parents, (2) having a sense of shame to violate the shari'a, (3) behaving based on Islamic shari'a, (4) time punctuality, (5) good moral characters. Finally, the findings reveal that the building of family-based Islamic characters in the Tablighi Jamaat community contributes to the positive effects of children's Islamic characters in family and community.
\end{abstract}

Abstrak: Penelitian ini bertujuan untuk mengeksplorasi bagaimana pembentukan karakter Islami anak berbasis keluarga dalam kelompok Jama'ah Tabligh. Penelitian ini menggunakan metode kualitatif dengan pendekatan etnografi, data penelitian diambil melalui wawancara langsung dengan sepuluh orang informan (kepala keluarga Jama'ah Tabligh), untuk memperkokoh data wawancara penulis melakukan observasi selama dua tahun dengan cara terlibat langsung mengikuti kegiatan Jama'ah Tabligh seperti Ijtima', Bayan Markas, Ta'lim Halaqah, Khuruj, Jaulah dan tidak jarang juga penulis bersilaturrahmi langsung ke rumah seluruh informan. Seluruh data wawancara dan observasi kemudian dianalisis secara tematik menggunakan software NVivo 12. Secara keseluruhan temuan penelitian mendapati lima tema utama hasil pembentukan karakter Islami anak berbasis keluarga dalam kelompok Jama'ah Tabligh. Lima tema tersebut yaitu: (1) berbakti kepada orang tua, (2) memiliki rasa malu melanggar Syari'at agama, (3) berperilaku sesuai aturan Syar'i, (4) memanfaatkan waktu dengan baik, (5) senang berbuat baik. 
Lima temuan dalam penelitian ini telah membuktikan bahwa, pembentukan karakter Islami anak berbasis keluarga dalam kelompok Jama'ah Tabligh telah berdampak baik terhadap karakter Islami anak dalam keluarga dan masyarakat.

Keywords: Character Building, family-based education, Tablighi Jamaat, Ethnographic, Thematic Analysis

\section{INTRODUCTION}

$\mathrm{T}$ lablighi Jamaat is a large Islamic missionary sect that was initially founded by Muhammad Ilyas bin Muhammad Ismail al-Kandahlawi alDoeband al-Jisti al-Hanafi. Kandahlawi signifies the homeland of the founder namely Kandahla in Saharanpur India, while Deoband refers to Doebandi, the largest Islamic school in India where Muhammad Ilyas obtained his Islamic study. Al Jisti implicates his sect and al-Hanafi signifies the mazhab he believed in (Aziz, 2004; Arifin, 2017). Muhammad Ilyas was born in $1303 \mathrm{H}$ in Kandahla, Saharanpur, India. He spent his childhood in the city before moving and settling in Nizamuddin, New Delhi, with his parents and siblings. That is the ultimate reason why the area of Nizamuddin is the basis of Tablighi Jamaah until today (Khalimi, 2010).

As time passed by the Tablighi Jamaah rapidly grows that the movement spread all over the world including Indonesia (Asriyani, 2020). According to Hasanah, (2014) the Islamic movement appeared in Indonesia in 1952 in masjid al-Hidayah Medan, however, the growth of the movement was not significant as the surrounding community was not familiar with the ideas and concept of religious conducts proposed by the Tablighi Jamaat. The new religious movement then has grown rapidly in 1974 as the community has been quite familiar with the new religious conduct supported by progressive changes of government system toward religious issues. The Tablighi Jamaat then found a mosque in Kebon Jeruk as their religious center (Husda, 2020).

Although the emergence of this movement is relatively new than other religious groups such as Muhammadiyah, Nahdatul Ulama, Persatuan Islam, and
Tarbiyah Islamiyah, the idea brought by Tablighi Jamaah is quickly and widely accepted among the Indonesian Muslim community because of its communicative and humanist da'wa (Hasanah, 2017).

Based on the researcher's observation who has actively and directly participated in various Tablighi Jamaat religious activities, the da'wah conducted by the group has its uniqueness which can be seen from the strategy. They are required to perform some trips or tours for a certain amount of time. The tour is conducted from one village to another or from one mosque to another which is well known as khuruj (proselytizing tour).

Besides Khuruj which is claimed as the "da'wa trademark" of the Tablighi Jamaat, another interesting fact that can be obtained during the observation is the method implemented to build Islamic moral characters for children within the Tablighi Jamaah family. There are at least four pivotal points that make the method is distinctive compared to other Islamic methods addressed to the building of children's moral character. First, families in Tablighi Jamaah tend to send their children to Islamic boarding schools for their formal education. Second, parents fully encourage their children to be Quran reciters and memorizers. Third, involving children in all da'wah movements, including khuruj. Fourth, requiring children to dress according to the Sunnah such as wearing robes or abaya, or using siwak. Those attributes are believed, at least, to have an impact on the children's Islamic personality in the future.

Parents are regarded as the first teachers for their children and responsible to determine their future (Ningrum, 2018). In their research, Murniyetti et al., (2016); Waluyo, (2017); Inten, (2017) \& Hasanah et al., (2019) state that parents are the first party 
who are responsible to give modeling good moral conduct and characters. Related to the issue proposed in this study, some studies were conducted by Bustamam, (2008); Kamalludin, (2018); Nurhayati, (2019); Zubaidillah \& Nuruddaroini, (2020); Nuraedah \& Mutawakkil, (2020) show that the educational method used by the parents in Tablighi Jamaah to educate their children to become religious and pious community members, the Quran reciters and memorizers who have good Islamic moral characters and conducts.

According to Islamic teaching, the building of initial Islamic characters for children is the main responsibility of their parents. The importance to build Islamic characters is equally pivotal as teaching the very basic Islamic creed (aqeedah) to their children (Naufal, 2019; Ghofur, 2020; Effendi, 2020). It is believed that the chosen education method and system in a family will stimulate children's Islamic moral character. As supported by Noor, (2012) \& Barra, (2014) Parents' choices and patterns in educating children in the family will be directly correlated to children's moral conduct that character building has to be initiated as early as possible, even before children are born.

A scholar in Islamic education, Al-Gazali, addressed specific attention related to early Islamic character building as he stated that the educational pattern and piety of the parents will greatly influence children's characters in the future (Al-Ghazali, 1982; Ningrum, 2018; Arifin, 2018; Nurwahidin \& Al-Asyhar, 2019). As it is described in an analogy that parents resemble farmers who are responsible to take care of their plants that once they find other plants or those that endanger their plants, they must clean and throw the damages away. The farmers are also required to water and fertilize their crops that they become good harvest (Kasmar et al., 2019).

There are numerous studies conducted related to Tablighi Jamaat. Generally, there are 5.990 articles related to the new Islamic movement digitally accessed in Google
Scholar, Science Direct, DOAJ, Taylor \& Francis dan J-STORE. However, after reviewing a number of the digital literature, it is obtained that the prior studies focus on the da'wah movement of the Tablighi Jamaah, response of the community toward the Islamic group, the concept of the ideology, method of the da'wah, as well as the communication pattern of this religious group. The topic which is related to the family-based building of Islamic characters for children in the Tablighi Jamaat community has not been discussed and elaborated. Thus, the issue regarding the educational pattern of building the Islamic characters for children conducted by various Islamic communities is significant to be explored and studied.

\section{METHOD}

The study uses a qualitative method with an ethnographic approach. According to Yin, (1994); Myers, (1999); Taylor, (2001); Altheide, (2004) the ethnographic approach is appropriate if the study is aimed at finding out and exploring the cultural characteristics of an individual or group of people. Meanwhile Skinner, (2013); Samnani \& Singh, (2013); Engkizar et al., (2018); Wijaya, (2018) refer that the ethnographic approach provides an opportunity to the researchers to continuously and simultaneously observe the object of the study. The ethnographic approach also enables the researcher to explore detailed, indepth, and comprehensive data. Thus, the ethnographic approach is appropriate to be used in the study due to the data collection and the objectives of the study.

The informants of the study were ten people (the Tablighi Jamaah family) who are residing in Padang, West Sumatera which are selected by using the purposive sampling technique. The selection is based on four criteria, namely having the competence to acquire the problems being studied, being active in the field being studied, having time to provide information to researchers, and being honest in providing information according to data and facts that occur in the 
field (Engkizar, et al., 2018; Rahawarin et al., 2020; Amnda et al., 2020).

Furthermore, the data of the study was collected through direct interviews with all informants using a set of interview protocols. Every individual was repeatedly interviewed for the consistency of their answer. The result of the interview is strengthened by direct observations that the researcher is actively involved in some activities performed by the Tablighi Jamaat in their base. Those activities are ijtima', Bayan Markaz, Ta'lim Halaqah, Khuruj, Jaulah, and informal visits to the ten informant's families. All interview and observation data were then analyzed thematically using NVivo 12 Software. According to Engkizar, et al., (2018); Maputra et al., (2020); Syafril et al., (2021) thematic with NVivo Software is an effective way for a researcher to analyze the results of the analysis so that it can be seen in detail and easily accessible.

\section{RESULTS AND DISCUSSION}

According to the analysis of the interviews, it is obtained that there are five findings (theme) of the family-based of building Islamic characters for children, namely: (1) good moral conduct to parents, (2) having a sense of shame to violate the shari'a, (3) behaving based on Islamic shari'a, (4) time punctuality, (5) good moral characters. The five findings are pictured by using NVivo 12 as seen in the following image:

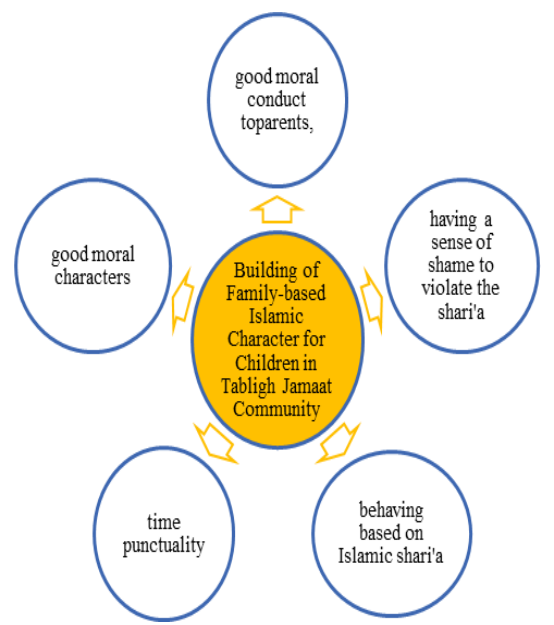

Image 1: Description of Five Themes of Familybased of Building Islamic Characters for
Children in Tablighi Jamaah Community by Using NVivo 12

Moreover, each finding will be elaborated in the discussion including some quotations conveyed by the informants during the interviews. Each theme will be discussed based on the theory, scholars' quotation, and findings of the previous studies which are related to the study.

First findings; filial piety to parents. Conducting filial piety to parents is an obligation performed by children required by Islamic teachings. The obligation to attribute filial piety to parents is also determined by the faith in Islam. The orders to pay good moral conduct to parents have been repeatedly commended by the Almighty SWT in the Holy Qoran as well as worded by the Prophet PUBH through some hadiths that the blessing of Allah SWR can be obtained if a person conducts the filial piety to his/her parents (Hamat, 2018; Adigun, 2019; Muhammad, 2020; Astuti, 2021). Although it is found in some cases that children and parents possess different faith, the obligation for filial piety goes beyond the difference of the faith. The obligation cannot be limited by faith differences.

The importance of paying the good moral conduct to parents leads to the urgency of Islamic character education unstoppable or inseparable from the children's education (Fahmi \& Susanto, 2018; Ulwiyah et al., 2019; Mustofa et al., 2020; Purwanto, 2021; Suyadi et al., 2021). Thus, the heads of families in Tablighi Jamaah pay serious attention to education that promotes Islamic moral characters to their children. One of the Islamic characters is promoting filial piety to parents. The following is the quotes of three informants related to the good moral conduct to parents:

"...educating children in our family is truly pivotal mainly building children character to have good conduct to parents. We prioritize education that promotes Islamic characters for our children for their future (Informant 1), as according to me the education that promotes Islamic characters 
involves many amiabilities including building the good moral conduct to parents (Informant 5),...That is why I and my wife prioritize educating our children on the importance of good conduct to their parents and the elders. This only can be obtained through Islamic education (Informant 7)".

Of the findings, the first value obtained in Islamic character education is promoting filial piety to parents. The fact can be seen from the children of the Tablighi Jamaah group that most of them respect parents and the elders, are polite, humorous, and caring to other fellows Muslims.

Second findings; behaving based on Islamic shari'a. As it is commonly known that families in Tablighi Jamaah are restrictive in following the shari'a on their daily basis that the restriction must be followed by their children without any exceptions. However, the important aspect that has to be emphasized to children is the consistency of being obedient toward the shari'a and promoting self-awareness to behave according to the rules of the shari'a.

Maintaining children's consistency and self-awareness to behave according to the Sharia from an early age is not an easy task for children. According to Afrilia \& Indriya, (2020); Wahyuni, (2020), low children's awareness to behave according to Islamic guidance is caused by the culture and basic education obtained by children in their family and immediate community. It implies that the attention and guidance from the parents since early age influence children self-awareness to permanently behave according to Islamic shari'a (Murniyetti et al., 2016). Related to the promotion of children self-awareness to behave according to Islamic shari'a, three informants gave the following statement:

"...I and my wife always put an effort to show our children how to behave according to the guidance of Islamic shari'a. It is crucial things that have to be done by parents that children's consistency and self-awareness to behave accordingly can be permanently built (Informant 2), ... oh Islamic attitude is not possible to be built and embedded as children basic characters if their parents do not model it in the family (Informant 4), ...like other families in Tablighi Jamaah community, I and my wife decide to prioritize religious education for our children, one of them is maximizing the character education since their early age (Informant 8)'”.

Based on the quotes of the interview, it is seen that Islamic character education leads children to behave according to the guidance of the Sharia (Wahyuni \& Putra, 2020). It is revealed by one of the informants that a significant change occurs in terms of children's behavior when the Islamic character education is promoted since childrens' early age. The changes do not only benefit the informant family but also the entire community of the Tablighi Jamaah who have been consistent in conducting the da'wa and promoting the Islamic character education since an early age.

The third finding; having a sense of shame to violate the shari'a. The third finding is parallel with the second one. When obedience toward the sharia has been instilled in children's behavior and attitude, the sense of shame to violet the guidance of the sharia is permanently and automatically embedded in children's personality. In this case, the parent's role is crucial in building this character as children's conduct and behavior are the reflection of their parents in the family (Porumbu \& Necşoi, 2013; Erzad, 2018; Cui et al., 2021; Iacopetti et al., 2021). Thus, families in Tablighi Jamaah emphasize instilling a sense of shame in violating the guidance of sharia. Three quotes are exhibited related to this finding as to the following statements:

“... children's education and moral characters much depend on their parents. Nowadays, many Muslim children are not embarrassed to violate the guidance of sharia. This 
also happens to elders in which they are not ashamed to disobey the sharia. To anticipate it, Islamic character education must be promoted from an early age by parents in the family. I and my wife agree that the promotion of character education must be maximized in our home (Informant 3$), \ldots$ children's sensitivity to feeling ashamed when they violate the sharia is the result of character education promoted by their parents at home (Informant 6), ...the importance to instill the sense of shame in violating the sharia is the ultimate reason to choose Islamic character education since our children early age. (Informant 9)".

The quotes signify that parent as a role model is irreplaceable as they are the ultimate role in modeling important moral, social and religious values (Çayak, 2021; Crosnoe, 2021; Murray, 2021). Families in the Tablighi Jamaah group are an example of success in guiding their children to possess a sense of shame to violate the sharia. Promoting the practice of Sunnah activity is one example of Islamic character education in a family.

The fourth finding; good moral character (happy to conduct charity). According to the Islamic perspective, every child has a true nature to perform good conduct as it is implied by the statement of one prominent Islamic scholar, Imam AlGazali, referring that a newborn child is likened to white sacred paper. However, their parents determine which colors will be inscribed on the white paper. It means that the children's moral character is determined by the education of their parents in the family (Kain et al., 2021; Liu \& Wang, 2021; Zhang \& Whitebread, 2021). Thus, Ginanjar, (2017); Amodia et al., (2020); Tan et al., (2020); Guo et al., (2021); Kallander et al., (2021) states that parents are the first institution responsible to give a role model to their children during their growth and development. This will affect children's character when they reach adulthood.
Educating children that they consistently do good deeds since an early age is not an easy task for parents. It requires maximum effort from the parents. Maximizing the Islamic character education is the first thing to do in the family of the Tablighi Jamaah that the habits of making good deeds can be instilled to their children as quoted from the three informants as the following:

"Educating children that they have good personality is determined by the parents in the family. To obtain it, we maximize the religious and character education to children (Informant 1), ...I think that there is better change to my children after they attend the congregation of Tablighi Jamaat as the teaching does not only guide the children to perform the religious activities (ibada), but also educate Islamic moral characters to children (Informant 10), ...as the da'wa of Tablighi Jamaat brings good changes to each consistent follower. Religion, social, moral and characters are the focus of their da'wa (Informant 7)".

Thus, the Islamic character education is regarded as a good tool to build the character of performing good deeds. Some parents in Tablighi Jamaah admitted that significant changes occur to their children when they implement Islamic character education in their family.

Fifth finding; good time management. Time management can be a serious problem for some people. Islam emphasizes the important skills of time management. Thus, parents will be happy if children could wisely make use of their time. As children's tendency to play, the surrounding community also affects children's ability to manage the time that it is not an easy task for children to make use of their time. Putri \& Lestari, (2016); Delprato, (2019); Ursache et al., (2019); Van Berkel et al., (2020); Tadakamadla et al., (2020); Burušić et al., (2021); Liu et al., (2021) states that serious and maximum guidance and control from parents are imperative that children can 
maximize positive activities, growth, and development on a daily basis.

The habit to make use of time wisely can be instilled through the guidance of the parents as the role model in the family (Avnet et al., 2019; Price \& Kalil, 2019; Khaidir \& Suud, 2020; Irastorza \& Elwert, 2021; Hémar-Nicolas et al., 2021; Kerr et al., 2021). In the family of Tablighi Jamaat, through the Islamic character education, it is imperative to train children to make use of their time as three informants are quoted as the following:

“...the ability to make use of time
cannot be built without Islamic
character education promotes to
children. It is only obtained through
the da'wa activities of Tablighi
Jamaah I have attended until this time
(Informant 2), ...yes, the skills of good
time management is one of the
benefits from attending the da'wa of
Tablighi Jamaah as it does not focus
merely on religious practices but also
social, Islamic moral and characters
(Informant 6), ...I think the best
solution is to promotes Islamic
character education to children. It is
already proved by the families of
Tablighi Jamaah (Informant 10)".

According to the interview, good time management is one of the benefits obtained from family-based Islamic character education practiced by the families of Tablighi Jamaah. The informants reported that significant changes occur after the parents attended and contributed to the da'wa of Tablighi Jamaah.

\section{CONCLUSION}

Building Islamic characters for children from an early age is a huge task and responsibility of parents who are regarded as the first teacher in the family. As the findings of the study show the children's Islamic characters are influenced by parents' habits and behavior at home. Besides parents' choice and guidance related to the children's education become the significant determiner. Five important characters which are the result of the building of children Islamic characters in families of Tablighi Jamaah are the positive pictures of Muslim families that become models as it is proved to have positive and consistent religious moral characters.

Based on the findings of the study, it is suggested to the next researchers to conduct more in-depth studies related to the issues that the literature regarding the study can be varied that the academicians and the community could have better ideas and notion of Islamic characters education. Other suggestions could be related to the correlation of parents' education level and children's academic achievement in Tablighi Jamaah, the effects of parents' education toward children's social intelligence in Tablighi Jamaah families as well as various issues related to this religious movement.

\section{REFERENCES}

Adigun, M. (2019). The implementation of the African charter on human and peoples' rights and the convention on the rights of the child in Nigeria: the creation of irresponsible parents and dutiful children?. The Journal of Legal Pluralism and Unofficial Law, 51(3), 320-349.

Afrilia, H., \& Indriya, I. (2020). Internalisasi Pendidikan Karakter Islami Anak Ditengah Pandemi Covid-19. Al-Fikr: Jurnal Pendidikan Islam, 6(2), 46-52.

Al-Ghazali, I. (1982). Al-Musthasyfa Min 'Ilmi Al-Ushul.

Altheide, D. L. (2004). Ethnographic content analysis. In The Sage encyclopedia of social science research methods, 1. 325-326.

Amnda, V., Wulandari, S., Wulandari, S., Syah, S. N., Restari, Y. A., Atikah, S., ..., \& Arifin, Z. (2020). Bentuk Dan Dampak Perilaku Bullying Terhadap Peserta Didik. Jurnal Kepemimpinan Dan Pengurusan Sekolah, 5(1), 19-32. http://dx.doi.org/10.34125/kp.v5i1.454

Amodia-Bidakowska, A., Laverty, C., \& Ramchandani, P. G. (2020). Fatherchild play: A systematic review of its 
frequency, characteristics and potential impact on children's development. Developmental Review, 57. 100924 https://doi.org/10.1016/j.dr.2020.10092 4

Arifin, Z. (2017). Authority of Spiritual Leadership at Pesantren Temboro Based on Jamaah Tabligh Ideology. Jurnal Pendidikan Islam, 6(2), 265-292.

Arifin, Z. (2018). Al-Ghazali's Thought of Islamic education and it's relevance with the modern education. Khalifa: Journal of Islamic Education, 2(1), 120.

http://dx.doi.org/10.24036/kjie.v2i1.18

Asriyani, Y. (2020). Efikasi Diri Istri Jamaah Tabligh Dalam Menjaga Keharmonisan Keluarga Menurut Hukum Islam (Studi Pada Jama'ah Tabligh Dalam Melakukan Khuruj di Dusun Kebon Bibit, Hajimena Natar Lampung Selatan). (Doctoral Dissertation, UIN Raden Intan Lampung)

Astuti, H. (2021). Berbakti Kepada Orang Tua dalam Ungkapan Hadis. Jurnal Riset Agama, 1(1), 45-58.

Avnet, M., Makara, D., Larwin, K. H., \& Erickson, M. (2019). The Impact of Parental Involvement and Education on Academic Achievement in Elementary School. International Journal of Evaluation and Research in Education, $8(3), 476-483$.

Aziz, A. (2004). The Jamaah Tabligh movement in Indonesia: Peaceful Fundamentalist. Studia Islamika, 11(3).

Barra, N. U. H. D. (2014). The impact of three religious' groups on the changing roles of Meranao women: a study of Tabligh Jamaah, Markazosshahab filFilibbin and Ahl al-Bayt. (Master's thesis, Kuala Lumpur: International Islamic University Malaysia, 2014).

Burušić, J., Šimunović, M., \& Šakić, M. (2021). Technology-based activities at home and STEM school achievement: the moderating effects of student gender and parental education. Research in Science \& Technological Education, 39(1), 1-22.
Bustamam-Ahmad, K. (2008). The history of Jama 'ah Tabligh in Southeast Asia: the role of Islamic Sufism in Islamic revival. Al-Jami'ah: Journal of Islamic Studies, 46(2), 353-400.

Çayak, S. (2021). Parents' Perceptions of School Climate as a Predictor of Parents' Participation in Their Children's Education. Acta Educationis Generalis, 11(1), 14-28.

Crosnoe, R. (2021). Parents, Their Children, and Their Children's Early Childhood Education Teachers. Advancing Knowledge and Building Capacity for Early Childhood Research, 91.

Cui, Y., Zhang, D., \& Leung, F. K. (2021). The influence of parental educational involvement in early childhood on 4th grade students' mathematics achievement. Early Education and Development, 32(1), 113-133.

Delprato, M. (2019). Parental education expectations and achievement for Indigenous students in Latin America: Evidence from TERCE learning survey. International Journal of Educational Development, 65, 10-25.

Effendi, D. I. (2020). The Identity Construction of Da'wah Leadership on Jama'ah Tabligh Movement. Ilmu Dakwah: Academic Journal for Homiletic Studies, 14(1), 133-150.

Engkizar, E., Alfurqan, A., Murniyetti, M., \& Muliati, I. (2018). Behavior and Factors Causing Plagiarism Among Undergraduate Students in Accomplishing the Coursework on Religion Education Subject. Khalifa: Journal of Islamic Education, 1(1), 98112.

http://dx.doi.org/10.24036/kjie.v1i1.8

Engkizar, E., Muliati, I., Rahman, R., \& Alfurqan, A. (2018). The Importance of Integrating ICT Into Islamic Study Teaching and Learning Process. Khalifa: Journal of Islamic Education, 1(2), 148-168. http://dx.doi.org/10.24036/kjie.v1i2.11

Erzad, A. M. (2018). Peran Orang Tua Dalam Mendidik Anak Sejak Dini Di 
Lingkungan Keluarga. ThufuLA: Jurnal Inovasi Pendidikan Guru Raudhatul Athfal, 5(2), 414-431.

Fahmi, M. N., \& Susanto, S. (2018). Implementasi Pembiasaan Pendidikan Islam dalam Membentuk Karakter Religius Siswa Sekolah Dasar. PEDAGOGIA: Jurnal Pendidikan, 7(2), 85-89.

Ghofur, A. (2020). Konsep Keluarga Dan Perempuan Dalam Perspektif Jamaah Tabligh: Analisa Normatif-Sosiologis. Ma'mun, 3(3), 69-95.

Ginanjar, M. H. (2017). Keseimbangan peran orang tua dalam pembentukan karakter anak. Edukasi Islami: Jurnal Pendidikan Islam, 2(03).

Guo, J., Zhang, J., \& Pang, W. (2021). Parental warmth, rejection, and creativity: The mediating roles of openness and dark personality traits. Personality and Individual Differences 168, 110369.

Hamat, M. A. A. (2018). Appraising the Legal Position of Parents Under The Qiṣāṣ Law: Immunity or A Waiver: تقييم الوضع القانوني للو الدين في القصاص: بين الحصانة و الإعفاء. International Journal of Fiqh and Usul Al-Fiqh Studies, 38-54.

Hasanah, U. (2014). Keberadaan Kelompok Jamaah Tabligh Dan Reaksi Masyarakat (Perspektif Teori Penyebaran Informasi Dan Pengaruh). Jurnal Indo-Islamika, 4(1), 21-44.

Hasanah, U. (2017). Jama'ah Tabligh I (Sejarah dan Perkembangan). El-Afkar: Jurnal Pemikiran Keislaman Dan Tafsir Hadis, 6(1), 1-10.

Hasanah, U., Alizamar, A., Marjohan, M., \& Engkizar, E. (2019). The Effect of Self Efficacy and Parent Support on Learning Motivation in Management Business Students in Padang's Private Vocational School. KONSELI: Jurnal Bimbingan Dan Konseling (E-Journal), 6(2), 133-140.

Hémar-Nicolas, V., Hapsari, H. P., Angka, S., \& Olsen, A. (2021). How cartoon characters and claims influence children's attitude towards a snack
vegetable-An explorative cross-cultural comparison between Indonesia and Denmark. Food Quality and Preference, 87, 104031.

Husda, H. (2020). Jamaah Tabligh Cot Goh: Historis, Aktivitas dan Respon Masyarakat. Jurnal Adabiya, 19(1), 2948.

Iacopetti, C., Londi, I., Patussi, V., \& Cosci, F. (2021). Family climate in children living with parents who harmfully consume alcohol. Clinical Psychology \& Psychotherapy.

Inten, D. N. (2017). Peran keluarga dalam menanamkan literasi dini pada anak. Golden Age: Jurnal Pendidikan Anak Usia Dini, 1(1).

Irastorza, N., \& Elwert, A. (2021). Like parents, like children? The impact of parental endogamy and exogamy on their children's partner choices in Sweden. Journal of Ethnic and Migration Studies, 47(4), 895-915.

Kain, A., Mueller, C., Golianu, B. J., Jenkins, B. N., \& Fortier, M. A. (2021). The impact of parental health mindset on postoperative recovery in children. Pediatric Anesthesia, 31(3), 298-308.

Kallander, E. K., Weimand, B. M., Hanssen-Bauer, K., Van Roy, B., \& Ruud, T. (2021). Factors associated with quality of life for children affected by parental illness or substance abuse. Scandinavian Journal of Caring Sciences, 35(2), 405-419.

Kamalludin, K. (2018). Pembinaan Keluarga Dalam Perspektif Jamaah Tabligh. Mizan: Journal of Islamic Law, 2(1).

Kasmar, I. F., Amnda, V., Mutathahirin, M., Maulida, A., Sari, W. W., Putra, S., \& Engkizar, E. (2019). The Concepts of Mudarris, Mu'allim, Murabbi, Mursyid, Muaddib in Islamic Education. Khalifa: Journal of Islamic Education, 3(2), 107125.

http://dx.doi.org/10.24036/kjie.v3i2.26

Kerr, Z. Y., Nedimyer, A. K., Kay, M. C., Chandran, A., Gildner, P., Byrd, K. H., \& Register-Mihalik, J. K. (2021). Factors associated with concussion- 
symptom knowledge and attitudes toward concussion care seeking in a national survey of parents of middleschool children in the US. Journal of Sport and Health Science, 10(2), 113121.

Khaidir, E., \& Suud, F. M. (2020). Islamic education in forming students' characters at as-shofa Islamic High School, pekanbaru Riau. International Journal of Islamic Educational Psychology, 1(1), 50-63.

Khalimi. (2010). Ormas-Ormas Islam: Sejarah, Akar Teologi dan Politik. Gaung Persada Press.

Liu, H., Chang, F., Corn, H., Zhang, Y., \& Shi, Y. (2021). The impact of parental migration on non-cognitive abilities of left behind children in northwestern China. Journal of Asian Economics, 72, 101261.

Liu, Q., \& Wang, Z. (2021). Associations between parental emotional warmth, parental attachment, peer attachment, and adolescents' character strengths. Children and Youth Services Review, 120, 105765.

Maputra, Y., Syafril, S., Wekke, I. S., Juli, S., Anggreiny, N., Sarry, S. M., \& Engkizar. (2020). Building Family's Social Resilience through Batobo Culture: A community environment proposal. IOP Conference Series: Earth and Environmental Science, 469(1). https://doi.org/10.1088/17551315/469/1/012062

Muḥammad, I. (2020). Birr al-Wālidayn: Being Dutiful to Parents. Turath Publishing.

Murniyetti, M., Engkizar, E., \& Anwar, F. (2016). Pola pelaksanaan pendidikan karakter terhadap siswa sekolah dasar. Jurnal Pendidikan Karakter, 6(2).

Murray, J. (2021). Informal early childhood education: the influences of parents and home on young children's learning. International Journal of Early Years Education, 29(2), 117-123.

Mustofa, M., Ahmadi, R., \& Karimullah, I. W. (2020). Islamic Character Education in E-Learning Model: How Should It be Implemented? Jurnal Sains Sosio Humaniora, 4(1), 89-93.

Myers, M. D. (1999). Investigating information systems with ethnographic research. Communications of the Association for Information Systems, 2(1), 23.

Naufal, M. (2019). Konsep Pendidikan Aqidah Perspektif Syaikh Muhammad Bin Abdul Wahhab Didalam Kitab Tauhid. (Doctoral Dissertation, UIN Raden Intan Lampung).

Ningrum, D. (2018). Kemerosotan moral di kalangan remaja: Sebuah penelitian mengenai parenting styles dan pengajaran adab. Unisia, 37(82), 18-30.

Noor, H. (2012). "Tauhid Sebagai Dasar Pendidikan Islam.” Al-'ulum, 53(3), 13-21.

Nuraedah, N., \& Mutawakkil, M. (2020). The Da'wah Communication Strategy of Jamaah Tabligh in Sub-district of Tondo, Palu City. Ilmu Dakwah: Academic Journal for Homiletic Studies, 14(2), 297-316.

Nurhayati, N. (2019). Khuruj and Family Economic Resilience: Study on Jama'ah Tabligh Family in Medan City. AlAhkam, 29(1), 67-84.

Nurwahidin, N. Q. M., \& Al-Asyhar, T. (2019). Children's Self-Acceptance Raised by Single Mother: Analysis Study in Moslem Family. Khalifa: Journal of Islamic Education, 3(2), 90106.

http://dx.doi.org/10.24036/kjie.v3i2.25

Porumbu, D., \& Necşoi, D. V. (2013). Relationship between parental involvement/attitude and children's school achievements. Procedia-Social and Behavioral Sciences, 76, 706-710.

Price, J., \& Kalil, A. (2019). The effect of mother-child reading time on children's reading skills: Evidence from natural within-family variation. Child Development, 90(6), e688-e702.

Purwanto, Y. (2021). Moderate Islamic Character Education In 4.0 Industrial Era. Psychology and Education Journal, 
58(1), 5356-5364.

Putri, D. P. K., \& Lestari, S. (2016). Pembagian peran dalam rumah tangga pada pasangan suami istri Jawa. Jurnal Penelitian Humaniora, 16(1), 72-85.

Rahawarin, Y., Engkizar, E., Hakim, R., Sari, W. W., Ramdani, N. S., Kasmar, I. F., Wulandari, S., Restari, Y. A., Mutathahirin, M., Amnda, V., \& Arifin, Z. (2020). Seven Motivations of Students Selecting Department of Islamic Teaching Education in Public University. Asian Social Science and Humanities Research Journal (ASHREJ), 2(1), 45-55. https://doi.org/10.37698/ashrej.v2i1.25

Samnani, A. K., \& Singh, P. (2013). Exploring the fit perspective: An ethnographic approach. Human Resource Management, 52(1), 123-144.

Skinner, J. (2013). The interview: An ethnographic approach (Vol. 49). A\&C Black.

Suyadi, S., Susilawati, S., \& Supriyatno, T. (2021). Islamic character education for student of public higher education in Indonesia.

Syafril, S., Yaumas, N. E., Engkizar, E., Jaafar, A., \& Arifin, Z. (2021). Sustainable Development: Learning the Quran Using the Tartil Method. Al-Ta Lim Journal, 28(1), 1-8.

Tadakamadla, S. K., Tadakamadla, J., Kroon, J., Lalloo, R., \& Johnson, N. W. (2020). Effect of family characteristics on periodontal diseases in children and adolescents-A systematic review. International Journal of Dental Hygiene, 18(1), 3-16.

Tan, C. Y., Lyu, M., \& Peng, B. (2020). Academic benefits from parental involvement are stratified by parental socioeconomic status: A meta-analysis. Parenting, 20(4), 241-287.

Taylor, S. (2001). Ethnographic research: A reader. Sage.

Ulwiyah, N., Maftuhatin, L., \& Samsukadi, M. (2019). Implementation of Islamic Character Education With Intervention Approach and Micro Habituation of
Education in Kuttab Al-Fatih Jombang. Didaktika Religia, 6(2), 245-272.

Ursache, A., Dawson-McClure, S., Siegel, J., \& Brotman, L. M. (2019). Predicting early emotion knowledge development among children of colour living in historically disinvested neighbourhoods: consideration of child pre-academic abilities, self-regulation, peer relations and parental education. Cognition and Emotion.

Van Berkel, S. R., Prevoo, M. J., Linting, M., Pannebakker, F. D., \& Alink, L. R. (2020). Prevalence of child maltreatment in the Netherlands: An update and cross-time comparison. Child abuse \& neglect. 103, 104439.

Wahyuni, I. W., \& Putra, A. A. (2020). Kontribusi peran orangtua dan guru dalam pembentukan karakter Islami anak usia dini. Jurnal Pendidikan Agama Islam Al-Thariqah, 5(1), 30-37.

Wahyuni, S. (2020). Pengenalan Perilaku

Keseharian Beragama Pada Anak Usia Dini. PROSIDING SEMINAR NASIONAL KEAGAMAAN (Vol. 1, No. 1).

Waluyo, K. E. (2017). Pendidikan Prenatal Dalam Membentuk Karakter Anak. Wahana Karya Ilmiah Pendidikan, 2(01).

Wijaya, H. (2018). Analisis Data Kualitatif Model Spradley (Etnografi). https://repository.sttjaffray.ac.id.

Yin, R. K. (1994). Case Study Research, Design and Methods, 2nd edition. Sage Publications.

Zhang, H., \& Whitebread, D. (2021). Identifying characteristics of parental autonomy support and control in parent-child interactions. Early Child Development and Care, 191(2), 307320.

Zubaidillah, M. H., \& Nuruddaroini, M. A. S. (2020). Konsep Pendidikan Anak Pada Keluarga Jama'ah Tabligh. AlMadrasah: Jurnal Pendidikan Madrasah Ibtidaiyah, 4(2), 155-172. 